\title{
An Investigation on Construction of Cultivating Modes for Critical Thinking Skills in College English Learning
}

\author{
Wang Lei \\ Foreign Language Department \\ Jilin Business and Technology College \\ Changchun, China \\ 182076127@qq.com
}

\begin{abstract}
With intensified international competition for talents, the critical thinking ability of college students has become the important content of college English education, and it plays an important role to cultivate students' critical thinking ability in the whole higher education. At present, what concerns the educators is the current situation of college students' critical thinking ability, though. All kinds of problems emerge endlessly hinder the pace of cultivating College Students' critical thinking. In this paper, the author will analyze the current situation of training the critical thinking in college English teaching from the connotation and function of critical thinking skills to construct the feasible training mode of critical thinking skills in college English teaching.
\end{abstract}

Keywords-College Reformation

\section{INTRODUCTION}

In China's College English teaching, although students' critical thinking ability has been of great importance to all educators, training effect is not obvious due to the restriction of all kinds of subjective and objective factors. Influenced by the traditional examination oriented education of the college English, teachers only require the students remember English knowledge---forcing students to remember and recite the words, sentences and classical texts, completely ignoring to cultivate students' critical thinking ability. With the advance of the pace of the reform of College English teaching, college English teaching emphasizes cultivating students' critical thinking ability. It's the precondition for cultivating students' critical thinking skills to understand concept and function of the critical ability.

Currently, attention is paid to the cultivation of students' critical thinking skills both in foreign and domestic education; in particular, the critical thinking skill is regarded as a key teaching point in higher education and its cultivation is considered as an essential teaching objective. The cultivation of students' critical thinking skills is more obvious in America and other developed countries where certain results have been achieved. The concept of critical thinking skills is introduced to Chinese higher education in 1980s. Although having made achievements in the research, the Chinese higher education still has defects in the cultivation of students' critical thinking skills In particular, the teachers should pay more attention to the cultivation of students' critical thinking skills; since English is an important language tool, the students should learn it so as to communicate with people in other countries; when communicating, the critical thinking skills should be taken into consideration. [1]

\section{A. Connotation and function of critical Skills}

The English names "Critical thinking skills", other researchers call it "thinking", or "critical thinking". But from its basic meaning, the author thinks that the critical thinking ability should include two aspects,--- one is thinking skills and methods, namely cognitive ability, the other is thinking attitude and personality traits, namely spirit temperament. These two aspects are a closely, inseparable integral. The author believes that evaluation is the core content as a speculative idea of individual significance and value of reflective thinking ability. In short, a series of knowledge and skills serve as the standard to judge and measure the thinking ability. Based the two aspects above, we should focus on the skills and methods of thinking, attitude and quality to cultivate the students' critical thinking skills.

It plays an important role to cultivate students' thinking ability in college English teaching. First of all, it's the important way for meet the university reform and realize the goal of cultivating talents of English teaching to cultivate students' English skills. At the beginning of the 80' last century, the cultivating of critical thinking ability has been listed as education goals of many nations. With the development of society, it also becomes the goal of college English teaching in China, which is also an important measure to cultivate innovative talents and promote the development and progress of the society. Secondly, it is beneficial to inducing students to think actively to cultivate critical thinking ability, which is the important way to cultivate students' innovative spirit and practical ability. Finally, cultivating critical thinking skills is beneficial to the cultivation of students' question consciousness, to promoting the in-depth thinking about the problems of students, to cultivating their questioning, probing into the questions, analyzing problems, answering question and then to achieving the understanding nature of things, so as to improve 
the students' comprehensive ability of using English continuously.[2]

\section{B. Current situation of critical thinking skills in college english teaching}

College English teaching does have substantial achievement since the reform of College English teaching. But some significant problems are also exposed, which seriously influences the efficiency of college English teaching. And the student's lacking of critical thinking and innovation ability has become fatal in the college English teaching.

1) Too much emphasis on mechanical memory, ignoring the students' logical thinking: Under the influence of traditional English education, some English teachers believe that it's the good way for students' improvement of English ability to make them repeat more, memorize more and recite more, ignoring the cultivation of critical thinking skills. So, in daily English teaching, teachers just make the students dictate, recite, which makes students' thinking in stagnant of short circuit state when encountering the questions such as theme analysis, process elaboration and analysis of resons. students often think fuzzily, fail to express the actual meaning, even all of them keep silent when the teacher have questions, which breaks the normal teaching atmosphere. Students have dialectical thinking consciousness, but the long-term linear thinking in English learning seriously hindered the students' thinking, students questioning and creating spirit are stifled.

2 ) Unconformity of perceptual cognition and rational cognition: Because of improper way of teaching or low rational understanding, the students tend to stay in the perceptual level of English event understanding, not to know essence from the phenomenon. Some students are often good at describing and stating, they will lose the sense of exploration and research direction especially in the face of some complicated problems. students will lose the sense of exploration and research direction, resulting in the confusion of thinking logic.

3) The practical application as the focus of teaching, neglecting the interest of culture: One of the most important teaching goal of English teaching is to cultivate students' English communicative ability, to make students understand, the cultural background of the English speaking countries, to increase knowledge, to enhance the sense of cultural identity, and then, improve the comprehensive quality of using English. Many English teachers take practical use as the core content of classroom teaching, thus ignoring the cultivation of students' interest and ability. For most students, the purpose of learning English is to graduate, get a good job and study abroad in the future, only a few of them are really interested in English learning. We pay more attention to innovating teaching mode, but to ignore the students' interest, resulting in the weaking of students' learning motivation.

\section{The CONSTRUCtion OF THE TRAINING MODE OF COLLEGE ENGLISH CRITICAL THINKING ABILITY}

\section{A. Reform of teaching design}

In order to cultivate the critical thinking skills, the teachers should pay attention to the teaching design reformation during the college English learning process. Currently, the undergraduates basically belong to the generation after 90s who contact with internet during the course of growing up and internet technology is developed and popularized constantly; therefore, the undergraduates at present all grew up under the internet environment. Internet exerts an enormous effect on undergraduate's learning and life because the internet is a expansive virtual space with open concept and flexible thought. The undergraduates in contemporary era all have independent thoughts and are enthusiastic about novelty with independent judgment; therefore, the traditional teaching design will make no difference on them. Hence, the teachers should design their own teaching method through combining with the characteristics of undergraduates and infusing internet knowledge so that the students can feel the value of studying and participate in the teaching activities actively. Meanwhile, the innovation of teaching design should be expanded based on textbooks so as to guarantee the effectiveness of the teaching design. [3]

In order to innovate the teaching design, the following two aspects should be taken into consideration: firstly, the problem setup in the textbooks should be innovated; although the problems in college English textbooks are representative, however, the problem setup fails to conform to the requirements of English teaching in contemporary era and thus the teachers should make the secondary processing on it during the teaching design process so that the teaching design can meet the requirements of critical classroom teaching; secondly, enough time and space should be given to the students so that they can apply it; the cramming method of teaching is not suitable for undergraduates in contemporary era who prefer to comprehend knowledge through applying so as to build the critical mode of theoretical knowledge and practical operation as well as enhance the cognitive level; hence, the teachers should take this into consideration during the teaching design process. For example, when explaining the environmental problem to students, the teachers can add the contents of sustainable development to expand the problem so as to combine it with the hot issues so that the speculation of classroom teaching can be enhanced.

\section{B. Depending on Classroom Teaching Contents}

The critical thinking skill is not an inborn competence and on the contrary it can be trained through acquired learning and training; therefore, the critical thinking skills should be cultivated through teachers' explanation and students' comprehension depending on the teaching contents in the English classroom. In general, the students can adjust and examine their own thinking ability due to the influence of critical thinking skill so that their subjective initiative can be presented effectively. In order to construct the teaching model for cultivation of college English critical thinking skills, the following two aspects should be taken into consideration: the 
first one is content-based teaching which refers to the effective cultivation of students' critical thinking skill and language competence through finding the combination between college English course content and critical thinking skill cultivation; the second one is independent course setting which cultivates the students' critical thinking skills through the training courses for critical thinking skills.[4] Hence, the college English teachers should make the most of and integrate the two methods so as to cultivate the critical thinking skills during English classroom teaching. There is intimate relationship between the cultivation of critical thinking skills and the learning of English knowledge; therefore, the teachers should widen the scope of English knowledge so as to cultivate the students' critical thinking skills.

\section{Encouraging Students to Query and Questioning}

Query and questioning is an effective method for cultivating students' critical thinking skills and thus the teachers should provide students with the opportunities to query and question during the English learning process so that they can obtain critical thinking skills. However, for the current situation of college English learning, many teachers do not pay attention to the query and questioning and the classes are characterized by tight schedule so that the students have no time to pose questions. Moreover, the teacher is the principal part in the classroom during the English classroom teaching and thus they may restrain the subjective initiatives of students during the teaching activities so that the students acquire knowledge passively; if the students are accustomed to this method, it will be disadvantageous to the cultivation of students' critical thinking skills.

Hence, teachers should stimulate students and leave enough time and space for them to speculate during the English teaching process so that they can pose questions; moreover, they should encourage students to query and question though this method so as to cultivate their critical thinking skills. The teachers should also change their teaching concept with the emphasis on the comprehension and acceptance of students instead of the teaching contents and thus the teachers should create a good query atmosphere, in which the students can deepen their cognition on questions through query and questioning so that their critical thinking skills can be enhanced and their comprehension on English knowledge can be profound.

\section{Training Students' Independent Learning Capability}

The independent study is an effective method for cultivating students' critical thinking skills and thus teachers should encourage students to do independent study, through which their critical thinking skills can be enhanced.[6] The independent study has high requirements on students and thus the students should be able to manage themselves effectively, formulate corresponding study plans autonomously and monitor themselves during the learning process. As a result, the students' critical thinking skills can be cultivated and their comprehensive abilities can be enhanced effectively through independent study; therefore, the construction of the cultivating mode for critical thinking skills in college English learning can't be separated from the application of independent study method.

The teachers should take the following aspects into consideration during the independent study process: firstly, the students should make rational design on the learning objective that should be multistep so that the students can realize it step by step; secondly, the students should be able to select the learning contents and design the learning progress so as to control the whole self-study process; thirdly, students should select the suitable learning styles and learning skills so as to do the independent study; besides, the students should be equipped with the ability to monitor the learning status strictly because they should be separated from the supervision of teachers and classmates during the independent study process; finally, the students should be able to make objective and fair evaluation on the learning effect so as to have an understanding of the self-study effect. Although the independent study should be done independently, the teachers should give them guidance and assistance during the initial stage of independent study so as to build up confidence for them. [5]

\section{E. Creating Critical Classroom Environment}

In order to cultivate the students' critical thinking skills, attention should be paid to the creation of critical classroom environment during the classroom teaching because it can help students improve the critical thinking skills. During the cultivation process of critical thinking skills, the emotional attitudes of undergraduates should be taken into consideration and the classroom atmosphere plays an important role in the emotional attitude, so the teachers should construct the critical classroom environment during the classroom teaching process so as to cultivate the students' critical thinking skills. In the traditional teacher-centered English classroom, the students can only passively acquire knowledge through the presupposed teaching model, restraining the subjective initiatives of students so that the enhancement of critical thinking skills is affected.

Hence, the teachers should take the following aspects into consideration so as to create the effective critical classroom environment: firstly, the teachers should establish relationship with students with the help of the popular network platform because most undergraduates are growing up in the network environment; for example, QQ, WeChat, microblog and other network platforms can be used to strengthen the communication between teachers and students so that the generation gap between them can be eliminated effectively and new teacher-student relationship can be built so as to make for the cultivation of students' critical thinking skills; secondly, the teachers should give students effective guidance and encourage so that they can participate in the teaching activities actively and provide them with critical teaching environment so that they can think deeply and cultivate critical thinking skills; finally, teachers should pay attention to students' advantages and strong points instead of deficiencies, encourage them to innovate and provide them with the opportunities to experience success, which is conducive to the improvement of students' critical thinking skills. 


\section{F. Improving Evaluation Mode of English Teaching}

In the traditional English teaching, the teachers tends to assess the students' learning condition through examinations which is characterized by strong boundedness; in particular, the main characteristics and teaching environment have changed greatly in contemporary society and the students' learning condition can't be reflected comprehensively through examination performance. Simultaneously, such teaching evaluation mode is adverse to the cultivation of students' critical thinking skills. Consequently, the teachers should improve the evaluation mode of English teaching and pay attention to the investigation on various abilities instead of applying single evaluation mode; for example, the debate can be added on the basis of traditional examination so as to train students the critical thinking skills; meanwhile, the contents of written examinations should be adjusted to reduce objective topics and increase subjective topics so as to assist in the cultivation and enhancement of students' critical thinking skills. Furthermore, the oral examination can be applied so that the students' oral English communicative competence can be trained and their critical thinking skills can be enhanced. Therefore, the changing of English evaluation mode is of great significance for improving students' critical thinking skills and thus the teachers should pay enough attention to it.

\section{CONCLUSIONS}

English is an important subject and instrument for undergraduates and the critical thinking skills are of great significance for them. Hence, the teachers should lay emphasis on the cultivation of critical thinking skill during the college
English learning process and adopt effective measures to attract the attention of students so as to construct the cultivating mode of critical thinking skills in college English learning through the joint efforts of teachers and students.

\section{REFERENCES}

[1] Tang Shanshan. A Discussion on Cultivating Mode of Critical Thinking Skills in College English Learning[J]. Campus English (Beginning),2015,(4):12-13.

[2] Wang Fang. A Discussion on Construction of Cultivating Mode for Critical Thinking Skills in College English Learning[J]. Journal of Jiamusi Occupational College,2015,(9):222-223.

[3] Xu Jing. A Study on Construction of Cultivating Mode for Critical Thinking Skills in College English Learning[J]. Journal of Taiyuan City Vocational College,2015,(3):122-123.

[4] Xu Jiju, Wang Shuwen, Lv Xuying er al. A Study on Construction of Cultivating Mode for Critical Thinking Skills in College English Learning[J].Time Education,2015,(9):7.

[5] Liu Xiaomin. On the cultivation mode of College English teaching and learning ability training mode [J]. Foreign LanguageWorld. 2013,05:5966.

[6] Xue Li. Analysis of English Teaching in the Construction of the Training Mode of Thinking Ability [J]..Campus English, 2014,28:47. 